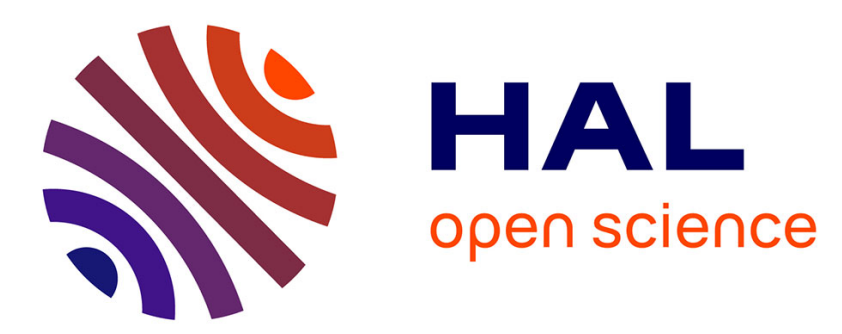

\title{
CD4 ligation excludes the Carma1-Bcl10-MALT1 complex from GM1-positive membrane rafts in CD3/CD28 activated T cells.
}

Maxime Rigo, Myriam Chentouf, André Pèlegrin, Thierry Chardès

\section{To cite this version:}

Maxime Rigo, Myriam Chentouf, André Pèlegrin, Thierry Chardès. CD4 ligation excludes the Carma1-Bcl10-MALT1 complex from GM1-positive membrane rafts in CD3/CD28 activated T cells.. Cellular Immunology, 2011, 270 (1), pp.40-6. 10.1016/j.cellimm.2011.03.025 . inserm-00588709

\section{HAL Id: inserm-00588709 https://www.hal.inserm.fr/inserm-00588709}

Submitted on 26 Apr 2012

HAL is a multi-disciplinary open access archive for the deposit and dissemination of scientific research documents, whether they are published or not. The documents may come from teaching and research institutions in France or abroad, or from public or private research centers.
L'archive ouverte pluridisciplinaire HAL, est destinée au dépôt et à la diffusion de documents scientifiques de niveau recherche, publiés ou non, émanant des établissements d'enseignement et de recherche français ou étrangers, des laboratoires publics ou privés. 
CD4 ligation excludes the Carma1-Bcl10-MALT1 complex from GM1-positive membrane rafts in CD3/CD28 activated T cells

Maxime Rigo ${ }^{\mathrm{a}}$, Myriam Chentouf ${ }^{\mathrm{a}}$, André Pèlegrin ${ }^{\mathrm{a}}$ and Thierry Chardès ${ }^{\mathrm{a}, *}$

${ }^{a} I R C M$, Institut de Recherche en Cancérologie de Montpellier, Montpellier, F-34298, France; INSERM, Unit 896, Montpellier, F-34298, France; Université Montpellier1, Montpellier, F-34298, France; CRLC Val d'Aurelle Paul Lamarque, Montpellier, F-34298, France

*Corresponding author: Institut de Recherche en Cancérologie de Montpellier, INSERM Unit 896/Université de Montpellier 1/CRLC Val d'Aurelle Paul Lamarque, 34298 Montpellier Cedex 5, France ; Tel. +33467612 404; Fax : +33467613787 ; E-mail address: thierry.chardes@valdorel.fnclcc.fr

$\dagger$ List of abbreviations: $\mathrm{ADCC}=$ antibody-dependent cell-mediated cytotoxicity, $\mathrm{APC}=$ antigen-presenting-cells, $\mathrm{Bcl10}=\mathrm{B}$ cell lymphoma 10 , Carma1 $=$ caspase-recruitment domainmembrane-associated guanylate kinase protein $1, \mathrm{CDC}=$ complement-dependent cytotoxicity, $\mathrm{EGFP}=$ enhance green fluorescent protein, $\mathrm{GM} 1=$ ganglioside $\mathrm{M} 1, \mathrm{IL}-2=$ interleukin $2, \mathrm{PKC}=$ protein kinase $\mathrm{C}, \mathrm{MAGUK}=$ membrane-associated guanylate kinase, $\mathrm{MALT} 1=$ mucosaassociated lymphoid tissue $1, \mathrm{NF}-\kappa \mathrm{B}=$ nuclear factor-kappa $\mathrm{B}, \mathrm{rgG}_{1=}$ recombinant $\operatorname{IgG}_{1}$, $\mathrm{TCR}=\mathrm{T}$ cell receptors, $\mathrm{ZAP}-70=$ zeta-chain-associated protein kinase of $70 \mathrm{kDa}$. 


\section{ABSTRACT}

The antibody 13B8.2, which is directed against the CDR3-like loop on the D1 domain of CD4, induces CD4/ZAP-70 reorganization and ceramide release in membrane rafts. Here, we investigated whether CD4/ZAP-70 compartmentalization could be mediated by an effect of 13B8.2 on the Carma1-Bcl10-MALT1 complex in membrane rafts. We report that treatment of CD3/CD28-activated Jurkat $\mathrm{T}$ cells with 13B8.2, but not rituximab, excluded Carma1Bcl10-MALT1 proteins from $\mathrm{GM}^{+}$membrane rafts and concomitantly decreased NF- $\mathrm{B}$ activation. Fluorescence confocal imaging confirmed that Carma1-Bcl10 and Carma1MALT1 co-patching, observed in $\mathrm{GM}^{+}$membrane rafts following $\mathrm{CD} 3 / \mathrm{CD} 28$ activation, were abrogated after a 24 h-treatment with 13B8.2. The CD4/ZAP-70 compartmentalization in membrane rafts induced by $13 \mathrm{~B} 8.2$ is thus related to Carma1-Bc110-MALT1 raft exclusion.

Key-words: antibody, raft, signalling, CD4, Carma1, cancer 


\section{Introduction}

The trans-membrane glycoprotein CD4 is a major component of the immunological synapse, which participates in the optimal activation of $\mathrm{T}$ lymphocytes during the immune response [1]. We previously demonstrated that the anti-CD4 $\mathrm{rgG}_{1} 13 \mathrm{~B} 8.2$ antibody inhibits $\mathrm{T}$ lymphocyte proliferation and IL-2 secretion [2], leading to growth arrest, ADCC and CDC of T lymphoma cells [3], through signals that prevent NF-кB nuclear translocation. Specifically, the $\mathrm{rgG}_{1} 13 \mathrm{~B} 8.2$ antibody induces CD4 accumulation in $\mathrm{GM} 1^{\dagger}$-positive membrane rafts and reorganization of signalling proteins involved in TCR-mediated immune response [4],

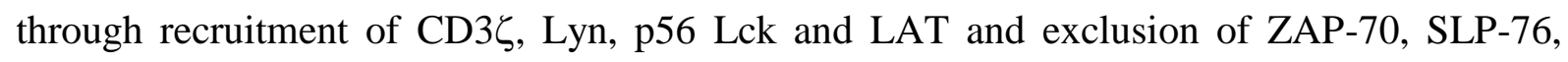
PLC $\gamma 1$ and Vav-1 from membrane rafts of Jurkat T cells [4]. Moreover, 13B8.2 increases ceramide release through acid sphingomyelinase activation and decreases phosphatidylserine synthesis without modifying the cholesterol content of GM1-positive membrane rafts [5]. However, we did not identify the link between the proximal modulation of the lipid-protein rheostat in membrane rafts and the downstream inhibition of NF- $\kappa \mathrm{B}$ observed following treatment with 13B8.2.

$\mathrm{T}$ cells activation by APC is triggered through co-stimulation of the TCR/CD3 complex and the CD28 receptor [6]. This co-stimulation (known as CD3/CD28 activation) induces transduction pathways that lead to the activation of tyrosine kinases (such as ZAP-70) and adapter proteins (like SLP-76 and Vav-1) that in turn induce the activity of multiple transcription factors, including $\mathrm{NF}-\kappa \mathrm{B}$, leading to $\mathrm{T}$ cell activation and proliferation. The scaffolding molecule Carma1, a member of the MAGUK family of proteins [7], is at the crossroads of the CD3- and CD28-induced pathways leading to NF- $\kappa \mathrm{B}$ activation. Carma1 is a lipid raft-associated regulator of TCR-induced NF- $\mathrm{BB}$ activation, located in the inner leaflet of the membrane [8]. Upon CD3/CD28-mediated PKC $\theta$ phosphorylation [9, 10], Carma1 is 
activated and promotes raft location of the downstream signalling proteins Bcl10 and MALT1 [11], thus forming the Carma1-Bcl10-MALT1 complex which modulates NF- $\kappa$ B by regulating the activation of the IKK complex [12].

We therefore wondered whether Carma1 could be involved in the raft reorganization induced by the 13B8.2 antibody and leading to NF- $\kappa \mathrm{B}$ inhibition in $\mathrm{CD} 3 / \mathrm{CD} 28$ activated $\mathrm{T}$ lymphoma cells. To this aim, we examined the raft localization of the Carma1-Bcl10-MALT1 complex following treatment with 13B8.2 and found that it dissociates and excludes this complex from GM1-positive membrane rafts in CD3/CD28 activated Jurkat T cells. 


\section{Materials and methods}

\subsection{Cells and reagents}

Jurkat T cells were provided by L. Briant (Centre National de la Recherche Scientifique Unité Mixte de Recherche 5236, Montpellier, France). Jurkat Green Fluorescent Protein cells (JGFP-1) [13] were kindly provided by X. Lin (School of Medicine and Biomedical Sciences, University at Buffalo, NY). Both cell lines were grown in RPMI 1640 (Cambrex) supplemented with $10 \%$ heat-inactivated FCS (PAA Laboratories), $100 \mathrm{U} / \mathrm{ml}$ penicillin and $100 \mu \mathrm{g} / \mathrm{ml}$ streptomycin (Sigma-Aldrich), and $2 \mathrm{mM}$ glutamine (complete medium). Recombinant $\operatorname{IgG}_{1}$ 13B8.2 antibody was purified from culture supernatant by protein $G$ immunoaffinity chromatography, as previously described [14]. The anti-CD3 (UCHT1) and anti-CD28 (CD28.2) monoclonal antibodies were from Beckman Coulter. Alexa Fluor 488and the peroxidase-conjugated cholera toxin B subunit were purchased from Molecular Probes (Invitrogen). Rabbit polyclonal antibodies against Bcl10 and MALT1 were from Cell Signaling Technology and goat anti-Carma1 antibody from Alexis Biochemicals. Brij98 detergent, peroxidase-conjugated anti-rabbit, anti-mouse, and anti-goat antibodies were from Sigma-Aldrich. Rhodamine- and fluorescein-conjugated anti-rabbit and anti-mouse antibodies were from Jackson ImmunoResearch.

\subsection{Lymphocyte treatment}

$1 \times 10^{8}$ Jurkat T cells were incubated with $10 \mu \mathrm{g} / \mathrm{ml} 13 \mathrm{~B} 8.2$ in complete medium at $37^{\circ} \mathrm{C}$ for $15 \mathrm{~min}, 4 \mathrm{~h}$ or $24 \mathrm{~h}$. In some experiments, T cells were pre-activated with $10 \mu \mathrm{g} / \mathrm{ml}$ antiCD3 and $10 \mu \mathrm{g} / \mathrm{ml}$ anti-CD28 antibodies, followed by cross- linking with $5 \mu \mathrm{g} / \mathrm{ml}$ rabbit anti- 
mouse IgG (Sigma-Aldrich) at $37^{\circ} \mathrm{C}$ for $4 \mathrm{~h}$, as previously described [8].

\subsection{Brij 98 raft isolation}

After washing in $160 \mathrm{mM}$ PBS (pH 7.4), cells were lysed at $37^{\circ} \mathrm{C}$ in $1 \%$ Brij 98 detergent diluted in TNE buffer (25 mM Tris-HCl, $\mathrm{pH}$ 7.5; $150 \mathrm{mM} \mathrm{NaCl} ; 5 \mathrm{mM}$ EDTA and $1 \mathrm{mg} / \mathrm{ml}$ enzyme inhibitors) (complete EDTA-free mixture of anti-proteases; Roche) for 30 min. Cell lysates were mixed with an equal volume of $80 \%$ sucrose in TNE, overlaid with 6.5 $\mathrm{ml}$ of $30 \%$ and $3.5 \mathrm{ml}$ of $5 \%$ sucrose in TNE, and then centrifuged at 200,000 $\mathrm{g}$ for $20 \mathrm{~h} \mathrm{[4}$, 5]. Twelve 1-ml fractions were collected on ice starting from the top of the gradient and numbered from 1 to 12 . The protein content of each fraction was quantified with the micro Bradford Protein Assay kit (Pierce) [4, 5]. GM1 and CD71 expression were used to discriminate between rafts and non-rafts fractions (see below).

\subsection{Dot blot analysis of GM1-enriched membrane rafts}

Nitrocellulose membranes (Hybond ECL; Amersham) were spotted with $2 \mu \mathrm{g}$ of proteins from each gradient fraction. Membranes were blocked with 5\% semi-skimmed milk in PBS containing $0.1 \%$ Tween 20 (PBS-T) at room temperature for $1 \mathrm{~h}$ and then incubated with peroxidase-conjugated cholera toxin B subunit $(1: 1000)$ at room temperature for $1 \mathrm{~h}$ (GM1 detection) or with an anti-CD71 rabbit antibody (1:1000) (Santa Cruz Biotech.) at $37^{\circ} \mathrm{C}$ for $1 \mathrm{~h}$ (CD71 detection), followed by a secondary peroxidase-conjugated anti-rabbit antibody (1:3000). After washing in PBS-T, binding was revealed with the ECL Western Blotting Detection Kit (Amersham) [4]. Neither the experiments performed for this paper, nor the dot 
blots/western blots we previously published [4, 5] showed GM1 and CD71 reactivity in fractions $1-3$ of the membrane raft gradient.

\subsection{SDS-polyacrylamide gel (SDS-PAGE) electrophoresis and western blotting}

Forty $\mu \mathrm{g}$ of each gradient fraction were separated on 12\% SDS-PAGE under reducing conditions and electrophoretically transferred to Immobilon $\mathrm{P}$ membranes (Bio-Rad). Membranes were blocked with $5 \%$ semi-skimmed milk in PBS-T at $37^{\circ} \mathrm{C}$ for $1 \mathrm{~h}$. After washing in PBS-T, membranes were incubated with anti-Carma1, -Bcl10 and -MALT1 antibodies $(1: 1000)$ at $4{ }^{\circ} \mathrm{C}$ for $18 \mathrm{~h}$. Membranes were then washed with PBS-T three times and incubated with secondary peroxidase-conjugated anti-rabbit or anti-goat antibodies (1:1000), as appropriate, at room temperature for $1 \mathrm{~h}$. After three washes in PBS-T, antibody binding was detected with the ECL Western Blotting Detection Kit [4, 5].

\subsection{Flow cytometry measurement of $N F-\kappa B$ activation}

EGFP fluorescence levels in JGFP-1 cells were assessed by flow cytometry. Cells

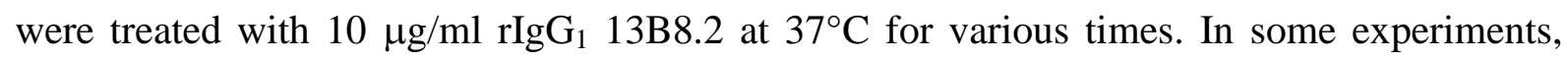
before antibody treatment, CD3/CD28 $\mathrm{T}$ cell activation was performed at $37^{\circ} \mathrm{C}$ for $4 \mathrm{~h}$. JGFP1 cells were then washed three times with PBS buffer without $\mathrm{Ca}^{++}$and $\mathrm{Mg}^{++}$and were suspended in PBS for analysis with an EPICS flow cytometer (Beckman-Coulter). 


\subsection{Confocal microscopy}

A total of $3 \times 10^{5} \mathrm{CD} 3 / \mathrm{CD} 28$-activated Jurkat $\mathrm{T}$ cells were treated with $\mathrm{rgG}_{1} 13 \mathrm{~B} 8.2$ at $37^{\circ} \mathrm{C}$ for $24 \mathrm{~h}$. After three washes in PBS, cells were fixed in $3 \%$ PFA/PBS (wt/vol) at room temperature for $15 \mathrm{~min}$ and then permeabilized with $0.1 \%$ Triton $\mathrm{X}-100$ at room temperature for 5 min. After three washes in PBS/2\% BSA (PBS-BSA), cells were incubated with Alexa Fluor 488-conjugated cholera toxin B subunit or anti-Carma1, -Bcl10, -MALT1 polyclonal antibodies (all at 1:1000) at room temperature for $1 \mathrm{~h}$ and then washed three times in PBS-BSA. Cells were incubated with secondary rhodamine-conjugated (for Bcl10 and MALT1 detection) or fluorescein-conjugated (for Carma1) antibodies (1:1000) at room temperature and in the dark for $1 \mathrm{~h}$. After three washes in PBS, cells were analyzed with a Nikon A1R confocal microscope (Montpellier RIO Imaging, CNRS UPR1142, Montpellier, France). Co-localization was assessed by excitation of the corresponding fluorochromes on the same sample. Negative controls lacking the primary antibody showed no staining. $Z$-axis acquisition was performed on five to ten different microscopic fields in the same slide from three to five independent experiments for each condition. For a given cell, the ratio of colocalization (Intensity Correlation Quotient or ICQ) was measured using the method described by $\mathrm{Li}$ and co-workers [15] and ImageJ software (http://rsbweb.nih.gov/ij/) and JACoP plugin [16]. This intensity correlation coefficient-based method processed image stacks by measuring pixel intensities to calculate the ICQ [17]. Briefly, when two proteins are part of the same complex their staining intensities will vary in synchrony (i.e., dependent staining); whereas if they are in different complexes they will exhibit asynchronous staining (i.e., segregated staining) [15]. The ICQ provides an overall index of whether the staining intensities are associated in a random, dependent or segregated manner [15]. ICQ values 
fluctuate from 0.5 (dependent staining, indicating co-localization) to -0.5 (segregated staining, demonstrating exclusion).

\subsection{Statistical analysis}

Results, when appropriate, were expressed as mean \pm SD and were the average of at least three different values per experiment. The Student's $t$-test was used to evaluate the statistical significance. Differences were considered statistically significant when $p<0.05$. 


\section{Results}

3.1. The recombinant anti-CD4 antibody $13 B 8.2$ concomitantly inhibits $N F-\kappa B$ and excludes the Carmal-Bcl10-MALT1 complex from $\mathrm{GM1}^{+}$membrane rafts in CD3/CD28 activated Jurkat T cells

To determine whether Carmal could be involved in the raft reorganization induced by 13B8.2, Jurkat $\mathrm{T}$ cells were pre-activated, or not, with CD3/CD28 antibodies for $4 \mathrm{~h}$ before treatment with 13B8.2. Controls were cells left untreated (medium alone), CD3/CD28activated cells and cells incubated with the anti-CD20 antibody rituximab with or without preactivation. Membrane fractions were then isolated by Brij98-extraction and characterized by dot blot analysis. GM1 expression (raft fractions) was mainly observed in fractions 4-6, whereas CD71 (non-raft fractions) was expressed in fractions 10-12. This distribution of raft and non-raft fractions was not influenced by the different treatments (Fig.1). Then, the localization of Carma1, Bcl10 and MALT1 in $\mathrm{GM}^{+}$raft and $\mathrm{CD}^{+} 1^{+}$non-raft fractions was investigated by western blotting (Fig.2). In the absence of CD3/CD28 activation, Carma1, Bcl10 and MALT1 were mainly located in the non-raft fraction 12 in untreated cells (Fig.2, left panel) and in cells incubated with 13B8.2 or rituximab for $15 \mathrm{~min}$ or $240 \mathrm{~min}$ (4 h) (Fig.2, left panel). Pre-activation with CD3/CD28 antibodies induced accumulation of Carma1, Bcl10 and MALT1 in raft fractions 4-6 (Fig.2, right panel). Conversely, when pre-activation was followed by a 15-min treatment with 13 B8.2 (Fig.2, right panel), but not with rituximab (Fig.2, right panel), these adapter proteins were partially segregated from $\mathrm{GM}^{+}$rafts and localized in fractions 8 and 9 and in the $\mathrm{CD}_{71}{ }^{+}$non-raft fraction 12 . This reorganization of the Carma1-Bcl10-MALT1 complex in fraction 12 was complete in CD3/CD28 activated Jurkat T cells that were treated with $\operatorname{rgG}_{1} 13 \mathrm{~B} 8.2$ for $240 \mathrm{~min}$ (Fig.2, right panel). 
These results indicate that 13B8.2 segregates the Carma1-Bcl10-MALT1 complex, which is involved in the pathway which leads to NF- $\kappa \mathrm{B}$ activation [10], outside membrane rafts. To investigate whether this exclusion could affect NF- $\mathrm{BB}$ activation, JGFP-1 Jurkat T cells, in which the enhanced green fluorescence protein (EGFP) is under the control of four tandem-repeats of a consensus NF- $\kappa \mathrm{B}$ binding sequence [13], were treated with $13 \mathrm{~B} 8.2$ or rituximab for $4 \mathrm{~h}$ or $24 \mathrm{~h}$ after or not CD3/CD28 activation and the fluorescence induced by $\mathrm{NF}-\kappa \mathrm{B}$ activation was measured. The number of EGFP-positive cells significantly increased in CD3/CD28-activated JGFP-1 cells in comparison to unstimulated cells, demonstrating NF$\kappa \mathrm{B}$ activation. Conversely, treatment of CD3/CD28 pre-activated JGFP-1 Jurkat $\mathrm{T}$ cells with 13B8.2, but not with rituximab, decreased significantly EGFP expression in comparison to untreated pre-activated cells. This inhibitory effect of $13 \mathrm{~B} 8.2$ was time-dependent as indicated by the stronger reduction in fluorescence after $24 \mathrm{~h}$-treatment $(30 \%)$ than after $4 \mathrm{~h}$ (15\%) (Fig.3).

3.2. GM1/Carmal co-patching is abrogated by $13 B 8.2$ treatment of CD3/CD28 activated Jurkat T cells

The effects of $13 \mathrm{~B} 8.2$ on Carma1 partitioning in raft/non-raft fractions were then investigated using confocal microscopy. Carma1 co-localization with GM1 was assessed in Jurkat $\mathrm{T}$ cells that had been left without treatment, pre-activated with CD3/CD28 antibodies, or incubated with $13 \mathrm{~B} 8.2$ or rituximab for $24 \mathrm{~h}$ after, or not, CD3/CD28 activation. GM1 and Carma1 co-patched in CD3/CD28 activated cells (Fig. 4A), but not in untreated cells (medium alone) or in cells incubated with 13B8.2. Conversely, in CD3/CD28 activated cells, 13B8.2 impaired GM1-Carma1 co-localization (Fig.4A). Quantification of the ratio of colocalization (Intensity Correlation Quotient, ICQ) showed that non-activated cells (untreated 
or treated with $13 \mathrm{~B} 8.2$ or rituximab) had ICQ values around 0.25 (Fig. 4B), in agreement with the absence of GM1 and Carma1 co-patching (Fig. 4A). Conversely, the ICQ of CD3/CD28activated cells was significantly increased to 0.45 , confirming the co-localization of GM1 and Carma1 (Fig. 4A). This value decreased significantly to 0.27 in CD3/CD28-activated cells treated with $13 \mathrm{~B} 8.2$, whereas it remained unchanged $(\mathrm{ICQ}=0.45)$ in $\mathrm{CD} 3 / \mathrm{CD} 28$-activated cells incubated with rituximab. These results indicate that GM1/Carma1 co-patching in CD3/CD28-activated Jurkat T cells is blocked by treatment with 13B8.2.

\subsection{The Carmal-Bcl10-MALT1 complex is disassembled by $13 B 8.2$ treatment}

To determine the consequences of 13B8.2 treatment on the Carma1-Bcl10-MALT1 complex after its reorganization outside $\mathrm{GM} 1^{+}$membrane rafts, Carma1, Bcl10 and MALT1 co-patching was assessed by confocal microscopy in Jurkat $\mathrm{T}$ cells that were or not activated with CD3/CD28 antibodies and treated or not with $13 \mathrm{~B} 8.2$ or rituximab for $24 \mathrm{~h}$. No copatching was observed, in untreated (medium) cells or after incubation with 13B8.2 (Fig. 5A and 5B), whereas in CD3/CD28 activated cells Carma1 co-localized with both Bcl10 (Fig. 5A) and MALT1 (Fig. 5B). Co-patching was abrogated when CD3/CD28-activated cells were incubated with 13B8.2. Quantification of the ICQ using up to ten separate staining areas in five independent experiments gave comparable results. Non-activated cells, untreated or treated with $\operatorname{rgG}_{1} 13 \mathrm{~B} 8.2$ or rituximab, had ICQ values around 0.23 (Fig. 5C) for both Carma1/Bc110 and Carma1/MALT1. Conversely, in CD3/CD28 activated cells, ICQ values increased significantly to 0.42 , confirming the co-localization of Carmal with Bcl10 or MALT1 (Fig. 5A and 5B). Treatment of CD3/CD28 activated cells with 13B8.2, but not with rituximab, decreased significantly the ICQ values for both Carma1/Bcl10 and Carma1/MALT1 from $0.41-0.42$ to $0.20-0.21$ respectively. These results indicate that the 
13B8.2 antibody inhibits co-patching of Carma1 with Bcl10 or MALT in CD3/CD28activated Jurkat T cells. 


\section{Discussion}

In this study we show that treatment of CD3/CD28-activated Jurkat T cells with the anti-CD4 $\mathrm{rgG}_{1}$ 13B8.2 antibody excludes Carma1-Bcl10-MALT1 proteins from GM1 ${ }^{+}$ membrane rafts and that this dissociation occurs concomitantly with the reduction of NF- $\mathrm{BB}$ activation. These results suggest that $13 \mathrm{~B} 8.2$ inhibits $\mathrm{NF}-\kappa \mathrm{B}$ signalling through the raft exclusion and consequent dissociation of the Carma1-Bcl10-MALT1 complex. We previously demonstrated that 13B8.2 induces acid sphingomyelinase activation and membrane ceramide release [5] together with CD4/ZAP-70 reorganization in membrane rafts [4]. Such events modulate the lipid-protein rheostat and might participate in the exclusion of the Carma1Bc110-MALT1 complex from membrane rafts.

Upon antigen-induced stimulation of the Carma1-Bcl10- MALT1 complex, NF-кB activation widely depends on Carmal phosphorylation. PKC $\theta$-triggered phosphorylation of Carmal occurs at Serine 564 and $657[18,19]$ and contributes to Carmal activation and assembly of the Carma1-Bcl10-MALT1 complex. A recent study, however, highlighted that a third PKC target site, Serine 649, triggers Carma1 down-regulation [20], but the PKC family member that phosphorylates this residue has not been yet identified. Ceramide also regulates negatively NF- $\kappa \mathrm{B}$ activation through inhibition of $\mathrm{PKC} \theta$ [21]. Based on this information we hypothesize that 13B8.2 could induce dissociation of the Carma1-Bcl10-MALT1 complex through ceramide release, which in turn might act as a PKC $\theta$ inhibitor, thus promoting Carma1 down-regulation by phosphorylation of Serine 649.

Deregulation of the Carma1-Bcl10-MALT1 complex plays a role in various diseases [22-26]. Carma1 is a possible target gene of the 7p22 amplification, which had been identified in aggressive adult T-cell leukaemia [26], as increased Carma1 transcription was observed. It also is over-expressed in angioimmunoblastic T-cell lymphoma and peripheral T- 
cell lymphoma [22] and is involved in the development of allergic airway inflammation [27]. Bc110 and MALT1 are over-expressed in MALT lymphomas due to the recurrent chromosomal translocations $\mathrm{t}(1 ; 14)(\mathrm{p} 22 ; \mathrm{q} 32), \mathrm{t}(11 ; 18)(\mathrm{q} 21 ; \mathrm{q} 21)$ and $\mathrm{t}(14 ; 18)(\mathrm{q} 32 ; \mathrm{q} 21)$ [23, $24,28]$. In all these cases, cells are 'supersensitized' to an antigen-induced signal leading to higher proliferation through $\mathrm{NF}-\kappa \mathrm{B}$ excessive activation.

Since the NF-אB pathway plays a pivotal role in promoting cell cycle progression, inhibiting apoptosis or regulating inflammation, NF- $\mathrm{BB}$ inhibitors could be of great interest in cancer therapy [29]. The first therapeutic attempts to target NF- $\mathrm{B}$ upstream regulators involved proteasome (PS-341, MG132), IKK (NSAID, thalidomide) or antioxidant (glutathione) inhibitors. Bortezomib, a proteasome inhibitor, was approved for multiple myeloma treatment [30] and has been assessed alone for the treatment of cutaneous T-cell lymphoma [31], or in combination with chemotherapy in aggressive T-cell leukaemia [32]. Then, research focused on NF- $\kappa \mathrm{B}$ RNA interference [33], microRNA therapy [34] or blockage of NF- $\kappa \mathrm{B}$ transcriptional activity [35]. However, most of these inhibitors lack specificity. Another class of upstream NF- $\mathrm{B}$ inhibitors, which targets IKK (such as BMS345541, SPC-839 or PS-1145 inhibitors) [36, 37], are in development and show more specificity. Based on the results of this paper, we hypothesize that indirect pharmacologic inhibition of the Carma1-Bcl10-MALT1 signalosome by antibodies could provide new ways to block the NF- $\kappa$ B pathway in a more tissue specific manner, which could contribute to the chemosensitization of lymphomas. 


\section{Acknowledgements}

We thank Geneviève Heintz for technical assistance, Dr Julien Cau (CNRS UPR1142, Montpellier, France) for microscopy assistance and Dr Xin Lin (University at Buffalo, USA) for kindly providing the JGFP1 cell line. This work was supported by a grant from the Ligue Nationale Contre le Cancer, Comité de l'Hérault. M.R. was a recipient of a doctoral fellowship from the Ligue Nationale Contre le Cancer, Comité de l'Hérault. M.C. was a recipient of a doctoral studentship from the Ligue Nationale contre le Cancer, Comité de l'Hérault, and the Association de Recherche contre le Cancer. 


\section{References}

[1] M.F. Krummel, M.M. Davis, Dynamics of the immunological synapse: finding, establishing and solidifying a connection, Curr. Op. Immunol. 14 (2002) 66-74.

[2] S. Troadec, C. Bès, M. Chentouf, B. Nguyen, L. Briant, C. Jacquet, M. Pugnière, F. Roquet, L. Briant-Longuet, M. Cérutti, T. Chardès, Biological activities on T lymphocytes of a baculovirus-expressed chimeric recombinant IgG1 antibody with specificity for the CDR3-like loop on the D1 domain of the CD4 molecule, Clin. Immunol. 119 (2006) 38-50.

[3] S. Troadec, M. Chentouf, B. Nguyen, M. Cérutti, D. Olive, C. Bès, T. Chardès, In vitro anti-tumoral mechanisms of baculovirus-expressed recombinant anti-CD4 antibody 13B8.2 on T cell lymphomas, J. Immunother. 30 (2007) 190-202.

[4] M. Chentouf, S. Ghannam, C. Bès, S. Troadec, M. Cérutti, T. Chardès, Recombinant anti-CD4 antibody 13B8.2 blocks membrane-proximal events by excluding the Zap70 molecule and downstream targets SLP-76, PLC gamma 1, and Vav-1 from the CD4segregated Brij 98 detergent-resistant raft domains, J. Immunol. 179 (2007) 409-420.

[5] M. Chentouf, M. Rigo, S. Ghannam, I Navarro-Teulon, S. Mongrand, A. Pèlegrin, T. Chardès. The lipid-modulating effects of a CD4-specific recombinant antibody correlate with ZAP-70 segregation outside membrane rafts. Immunol. Lett. 133 (2010) 62-69.

[6] A. Poggi, C. Bottino, M.R. Zocchi, G. Pantaleo, E. Ciccone, C. Mingari, L. Moretta, A. Moretta, CD3+ WT31- peripheral T lymphocytes lack T44 (CD28), a surface molecule involved in activation of T cells bearing the alpha/beta heterodimer, Eur. J. Immunol. 17 (1987) 1065-1068.

[7] O. Gaide, F. Martinon, O. Micheau, D. Bonnet, M. Thome, J. Tschopp, Carma1, a CARD-containing binding partner of Bcl10, induces Bcl10 phosphorylation and NF- 
kappaB activation, FEBS Lett. 496 (2001) 121-127.

[8] O. Gaide, B. Favier, D.F. Legler, D. Bonnet, B. Brissoni, S. Valitutti, C. Bron, J. Tschopp, M. Thome, CARMA1 is a critical lipid raft-associated regulator of TCRinduced NF-kappa B activation, Nat. Immunol. 3 (2002) 836-843.

[9] H. Hara, T. Wada, C. Bakal, I. Kozieradzki, S. Suzuki, N. Suzuki, M. Nghiem, E.K. Griffiths, C. Krawczyk, B. Bauer, F. D'Acquisto, S. Ghosh, W.C. Yeh, G. Baier, R. Rottapel, J.M. Penninger, The MAGUK family protein CARD11 is essential for lymphocyte activation, Immunity 18 (2003) 763-775.

[10] T. Egawa, B. Albrecht, B. Favier, M. Sunshine, K. Mirchandani, W. O'Brien, M. Thome, D.R. Littman Requirement for CARMA1 in antigen receptor-induced NF-kappa B activation and lymphocyte proliferation, Curr. Biol. 13 (2003) 1252-1258.

[11] T. Che, Y. You, D. Wang, M.J. Tanner, V.M. Dixit, X. Lin, MALT1/paracaspase is a signaling component downstream of CARMA1 and mediates $\mathrm{T}$ cell receptor-induced NF-kappaB activation, J Biol Chem. 279 (2004) 15870-15876.

[12] S.C. Bunnell, Determining the destiny of NF-kappa B after TCR ligation: it's CARMA1, Mol. Interv. 2 (2002) 356-360.

[13] D. Wang, Y. You, S.M. Case, L.M. McAllister-Lucas, L. Wang, P.S. DiStefano, G. Nuñez, J. Bertin J, X. Lin, A requirement for CARMA1 in TCR-induced NF-kappa B activation, Nat. Immunol. 3 (2002) 830-835.

[14] C. Bès, M. Cèrutti, L. Briant-Longuet, D. Bresson, S. Péraldi-Roux, M. Pugnière, J-C. Mani, B. Pau, C. Devaux, C. Granier, G. Devauchelle, T. Chardès, The chimeric mousehuman anti-CD4 Fab 13B8.2 expressed in baculovirus inhibits both antigen presentation and HIV-1 promoter activation, Hum. Antibodies 10 (2001) 67-76.

[15] Q. Li, A. Lau, T.J. Morris, L. Guo, C.B. Fordyce, E.F. Stanley, A syntaxin 1, Galpha(o), and N-type calcium channel complex at a presynaptic nerve terminal: analysis by 
quantitative immunocolocalization, J. Neurosci. 24 (2004) 4070-4081.

[16] P. Sperisen, M. Pagni, JACOP: a simple and robust method for the automated classification of protein sequences with modular architecture, BMC Bioinformatics 6 (2005) 216-228.

[17] S. Bolte, F.P. Cordelières, A guided tour into subcellular colocalization analysis in light microscopy, J. Microscopy 224 (2006) 213-232.

[18] R. Matsumoto, D. Wang, M. Blonska, H. Li, M. Kobayashi, B. Pappu, Y. Chen, D. Wang, X. Lin, Phosphorylation of CARMA1 plays a critical role in T Cell receptormediated NF-kappaB activation, Immunity 23 (2005) 575-585.

[19] K. Sommer, B. Guo, J.L. Pomerantz, A.D. Bandaranayake, M.E. Moreno-García, Y.L. Ovechkina, D.J. Rawlings, Phosphorylation of the CARMA1 linker controls NF-kappaB activation, Immunity. 23 (2005) 561-74.

[20] M.E. Moreno-Garcia, K. Sommer, C. Haftmann, C. Sontheimer, S.F. Andrews, D.J. Rawlings, Serine 649 Phosphorylation within the Protein Kinase C-Regulated Domain Down-Regulates CARMA1 Activity in Lymphocytes, J. Immunol. 183 (2009) 73627370.

[21] N. Abboushi, A. El-Hed, W. El-Assaad, L. Kozhaya, M.E. El-Sabban, A. Bazarbachi, R. Badreddine, A. Bielawska, J. Usta, G.S. Dbaibo, Ceramide inhibits IL-2 production by preventing protein kinase C-dependent NF-kappaB activation: possible role in protein kinase Ctheta regulation, J. Immunol. 173 (2004) 3193-3200.

[22] S. Fujiwara, Y. Yamashita, N. Nakamura, Y.L. Choi, T. Ueno, H. Watanabe, K. Kurashina, M. Soda, M. Enomoto, H. Hatanaka, S. Takada, M. Abe, K. Ozawa, H. Mano, High-resolution analysis of chromosome copy number alterations in angioimmunoblastic T-cell lymphoma and peripheral T-cell lymphoma, unspecified, 
with single nucleotide polymorphism-typing microarrays, Leukemia. 22 (2008) 18911898.

[23] Y. Hosokawa, H. Suzuki, Y. Suzuki, R. Takahashi, M. Seto, Antiapoptotic function of apoptosis inhibitor 2-MALT1 fusion protein involved in $\mathrm{t}(11 ; 18)(\mathrm{q} 21 ; \mathrm{q} 21)$ mucosaassociated lymphoid tissue lymphoma, Cancer Res. 64 (2004) 3452-3457.

[24] L. Ho, R.E. Davis, B. Conne, R. Chappuis, M. Berczy, P. Mhawech, L.M. Staudt, J. Schwaller, MALT1 and the API2-MALT1 fusion act between CD40 and IKK and confer NF-kappa B-dependent proliferative advantage and resistance against FAS-induced cell death in B cells, Blood. 105 (2005) 2891-2899.

[25] M.T. Tian, G. Gonzalez, B. Scheer, A.L. DeFranco, Bcl10 can promote survival of antigen-stimulated B lymphocytes, Blood. 106 (2005) 2105-2112.

[26] A. Oshiro, H. Tagawa, K. Ohshima, K. Karube, N. Uike, Y. tashiro, A. Utsunomiya, M. Masuda, N. takasu, S. Nakamura, Y. Morishima, M. Seto, Identification of subtypespecific genomic alterations in aggressive adult T-cell leukemia/lymphoma, Blood 107 (2006) 4500-4507.

[27] B.D. Medoff, B. Seed, R. Jackobek, J. Zora, Y. Yang, A.D. Luster, R. Xavier, CARMA1 is critical for the development of allergic airway inflammation in a murine model of asthma, J Immunol. 176 (2006) 7272-7277.

[28] I.A. Auer, R.D. Gascoyne, J.M. Connors, F.E. Cotter, T.C. Greiner, W.G. Sanger, D.E. Horsman, $\mathrm{t}(11 ; 18)(\mathrm{q} 21 ; \mathrm{q} 21)$ is the most common translocation in MALT lymphomas, Ann. Oncol. 8 (1997) 979-985.

[29] M. Cortés Sempere, V. Rodríguez Fanjul, I. Sánchez Pérez, R. Perona, The role of the NFkappaB signalling pathway in cancer, Clin. Transl. Oncol. 10 (2008) 143-147.

[30] M. Cavo, Proteasome inhibitor bortezomib for the treatment of multiple myeloma, Leukemia. 20 (2006) 1341-1352. 
[31] P.L. Zinzani, G. Musuraca, M. Tani, V. Stefoni, E. Marchi, M. Fina, C. Pellegrini, L. Alinari, E. Derenzini, A. de Vivo, E. Sabattini, S. Pileri, M. Baccarani, Phase II trial of proteasome inhibitor bortezomib in patients with relapsed or refractory cutaneous T-cell lymphoma, J. Clin. Oncol. 25 (2007) 4293-4297.

[32] J. Lee, C. Suh, H.J. Kang, B. Ryoo, J. Huh, Y.H. Ko, H.S. Eom, K. Kim, K. Park, W.S. Kim, Phase I study of proteasome inhibitor bortezomib plus CHOP in patients with advanced, aggressive T-cell or NK/T-cell lymphoma, Ann. Oncol. 19 (2008) 2079-2083.

[33] K.A. Higgins, J.R. Perez, T.A. Coleman, K. Dorshkind, W.A. McComas, U.M. Sarmiento, C.A. Rosen, R. Narayanan, Antisense inhibition of the p65 subunit of NFkappa B blocks tumorigenicity and causes tumor regression, Proc. Natl. Acad. Sci. U.S.A. 90 (1993) 9901-9905.

[34] A.L. Kasinski, F.J. Slack, Potential microRNA therapies targeting Ras, NFkappaB and p53 signaling, Curr. Opin. Mol. Ther. 12 (2010) 147-157.

[35] D. De Stefano, G. De Rosa, R. Carnuccio, NFkappaB decoy oligonucleotides, Curr. Opin. Mol. Ther. 12 (2010) 203-213.

[36] J.R. Burke, M.A. Pattoli, K.R. Gregor, P.J. Brassil, J.F. MacMaster, K.W. McIntyre, X. Yang, V.S. Iotzova, W. Clarke, J. Strnad, Y. Qiu, F.C. Zusi, BMS-345541 is a highly selective inhibitor of I kappa B kinase that binds at an allosteric site of the enzyme and blocks NF-kappa B-dependent transcription in mice, J. Biol. Chem. 278 (2003) 14501456.

[37] A.C. Castro, L.C. Dang, F. Soucy, L. Grenier, H. Mazdiyasni, M. Hottelet, L. Parent, C. Pien, V. Palombella, J. Adams, Novel IKK inhibitors: beta-carbolines, Bioorg. Med. Chem. Lett. 13 (2003) 2419-2422. 


\section{Figure legends}

Fig. 1. Dot blot characterization of Brij 98-extracted fractions. Jurkat T cells were preactivated or not with $\mathrm{CD} 3 / \mathrm{CD} 28$ antibodies and treated with the anti-CD4 $\mathrm{rgG}_{1} 13 \mathrm{~B} 8.2$ or the anti-CD20 antibody rituximab. Cells were then lysed with Brij 98 detergent at $37^{\circ} \mathrm{C}$ and separated into fractions by sucrose density gradient. Fraction 12 represents the bottom liquid fraction of the density gradient. Membrane rafts are in fractions 4-6, as indicated by GM1 expression, whereas non-raft fractions $10-12$ are identified by CD71. Results are representative of at least three independent experiments.

Fig. 2. Localization of the Carma1-Bcl10-MALT1 complex in Brij98-extracted, raft and nonraft fractions of Jurkat T cells pre-activated (right panels) or not (left panels) with CD3/CD28 antibodies and then left untreated or treated with 13B8.2 or rituximab for $15 \mathrm{~min}$ or $240 \mathrm{~min}$. The data represent one of three independent experiments.

Fig 3. The anti-CD4 rIgG1 13B8.2 antibody reduces NF-kB activation in Jurkat $\mathrm{T}$ cells. JGFP-1 Jurkat $\mathrm{T}$ cells, in which the enhanced green fluorescence protein (EGFP) is under the control of four tandem-repeats of a consensus NF- $\mathrm{BB}$ binding sequence, were left untreated (medium), pre-activated with CD3/CD28 antibodies, or incubated with $13 \mathrm{~B} 8.2$ or rituximab for $4 \mathrm{~h}$ and $24 \mathrm{~h}$ after, or not, CD3/CD28 activation. NF- $\mathrm{kB}-$ dependent EGFP expression was quantified after $4 \mathrm{~h}$ (black bar) or $24 \mathrm{~h}$ (white bar). (*p<0.05, **p< 0.005$)$.

Fig. 4. Carma1 differential partitioning in raft and non-raft fractions following treatment with 13B8.2. Jurkat $\mathrm{T}$ cells were left untreated (medium), pre-activated with $\mathrm{CD} 3 / \mathrm{CD} 28$ antibodies, or incubated with $13 \mathrm{~B} 8.2$ or rituximab for $24 \mathrm{~h}$ after or not CD3/CD28 activation. (A) After the different treatments, cells were incubated with Alexa Fluor 488-conjugated 
cholera toxin B subunit, which binds to GM1-enriched fractions, or with anti-Carma1 polyclonal antibodies followed by a secondary TRITC-conjugated antibody and then analysed by confocal microscopy (B) GM1/Carmal clustering was quantified using the method described by Li and co-workers with JACoP/ImageJ software. $\left({ }^{* *} p<0.005\right)$.

Fig. 5. Carma1/Bcl10 and Carma1/MALT1 differential partitioning following treatment with rIgG1 13B8.2. Jurkat $\mathrm{T}$ cells were left untreated (medium), pre-activated with $\mathrm{CD} 3 / \mathrm{CD} 28$ antibodies, or incubated with $13 \mathrm{~B} 8.2$ or rituximab for $24 \mathrm{~h}$ after, or not, CD3/CD28 activation. Co-localization of the different components of the Carma1-Bcl10-MALT1 complex was assessed by confocal microscopy using anti-Carma1 and anti-Bc110 (A) or antiCarma1 and anti-MALT1 (B) polyclonal antibodies followed by the appropriate secondary FITC- or TRITC-conjugated antibody. (C) Carma1/Bcl10 and Carma1/MALT1 clustering was quantified using the method described by Li and co-workers with JACoP/ImageJ software. $(* * p<0.005)$. 


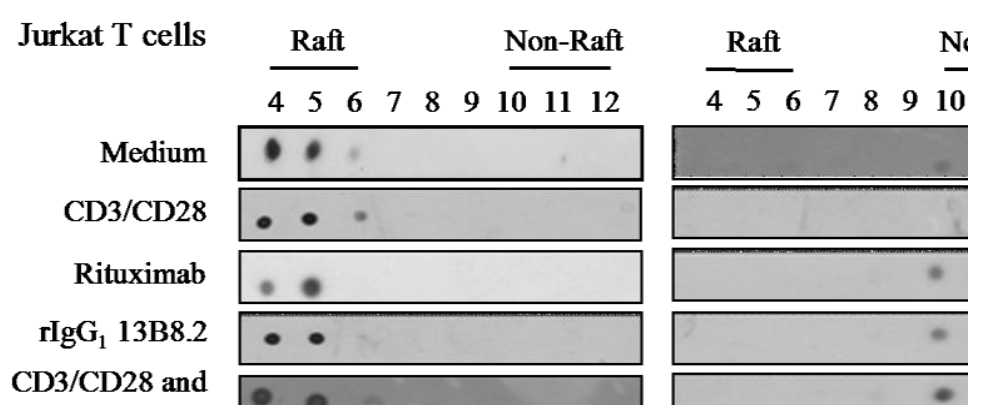




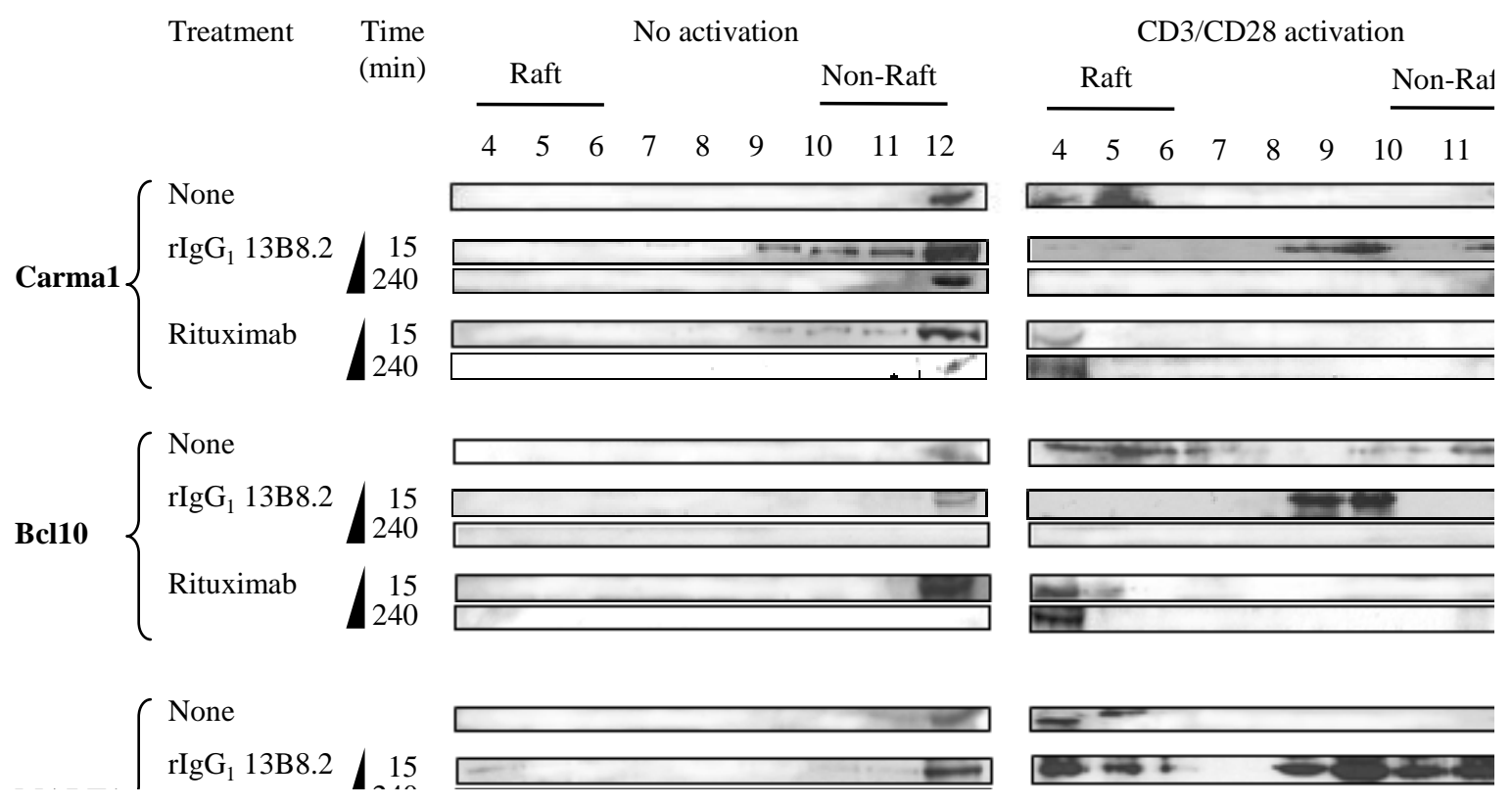




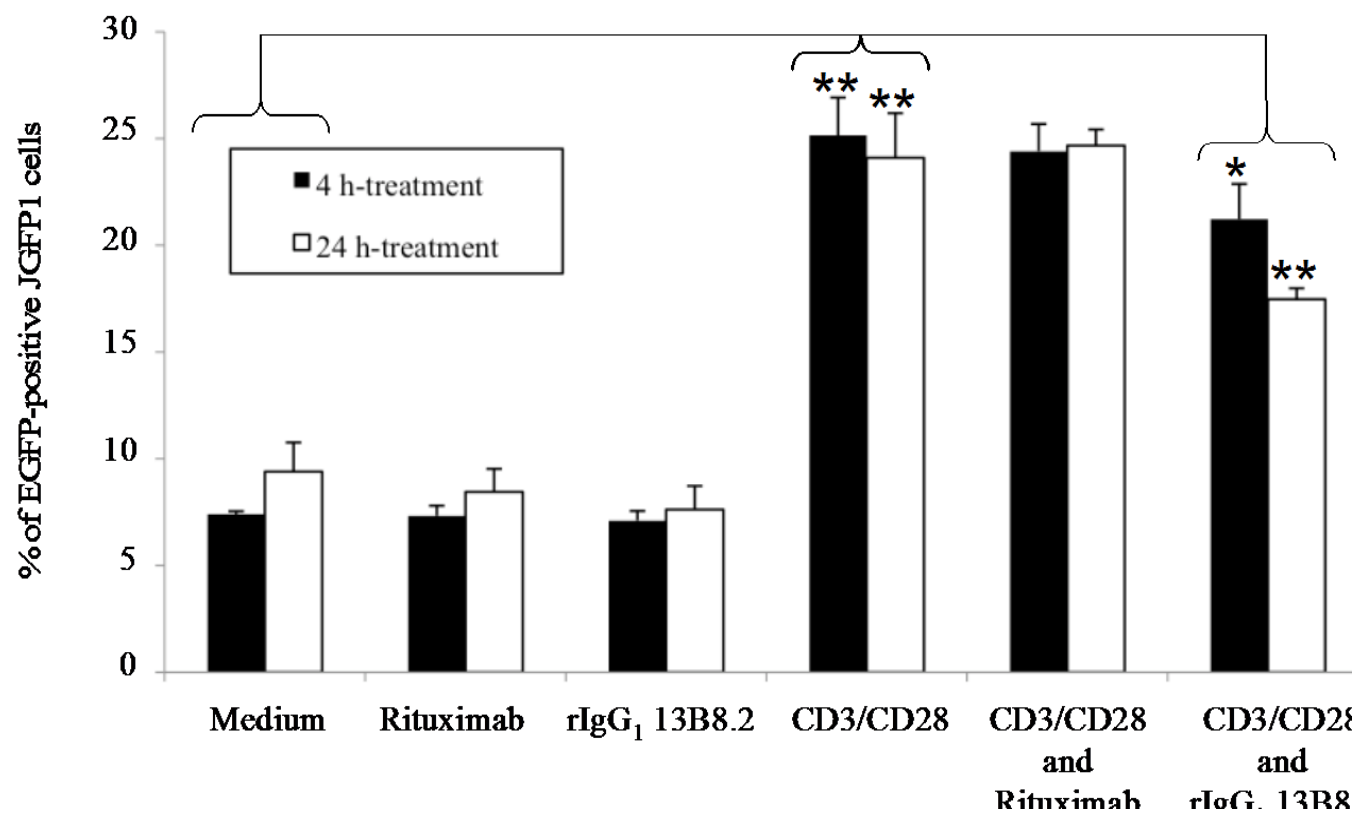




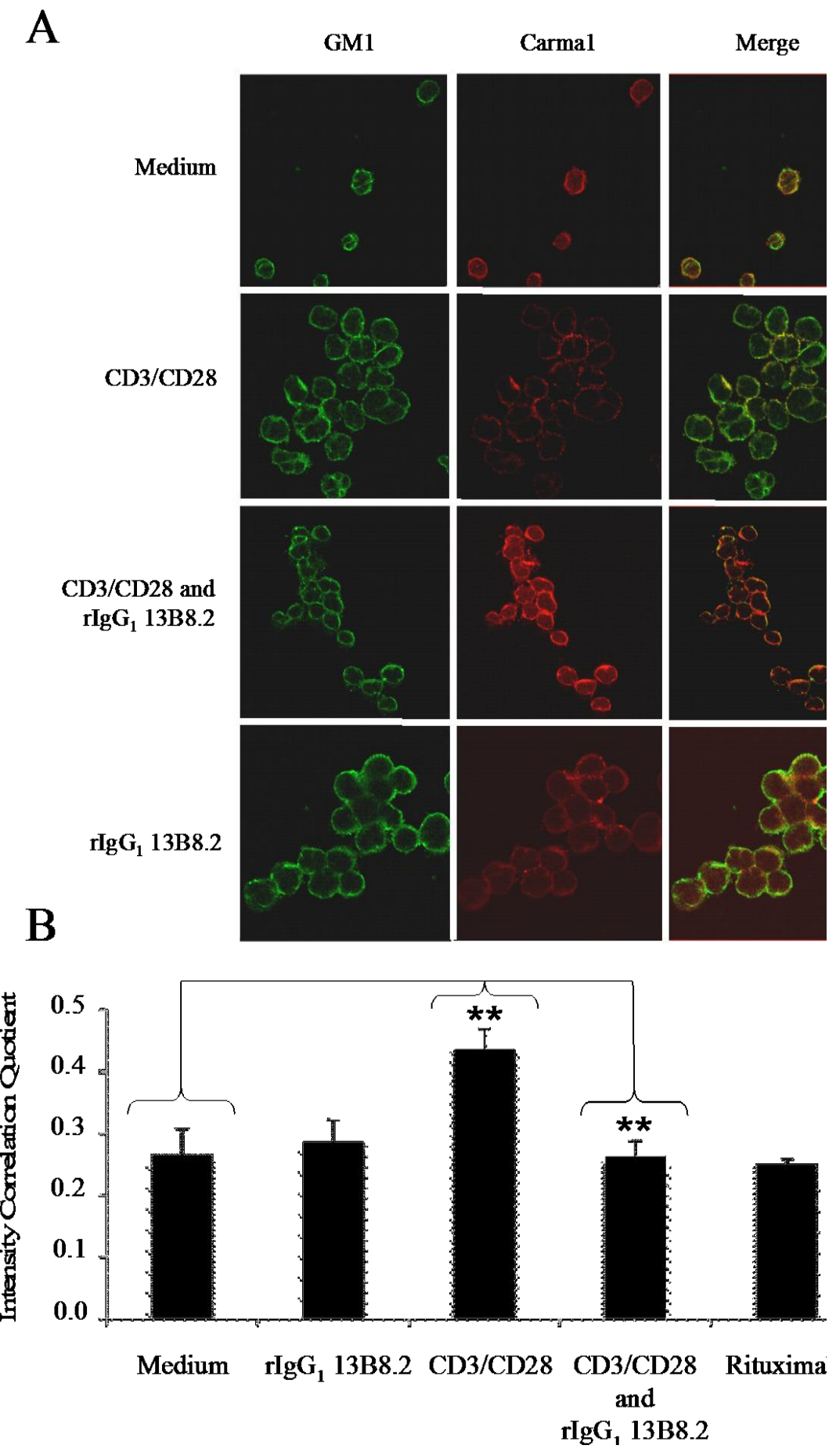


Fig.5
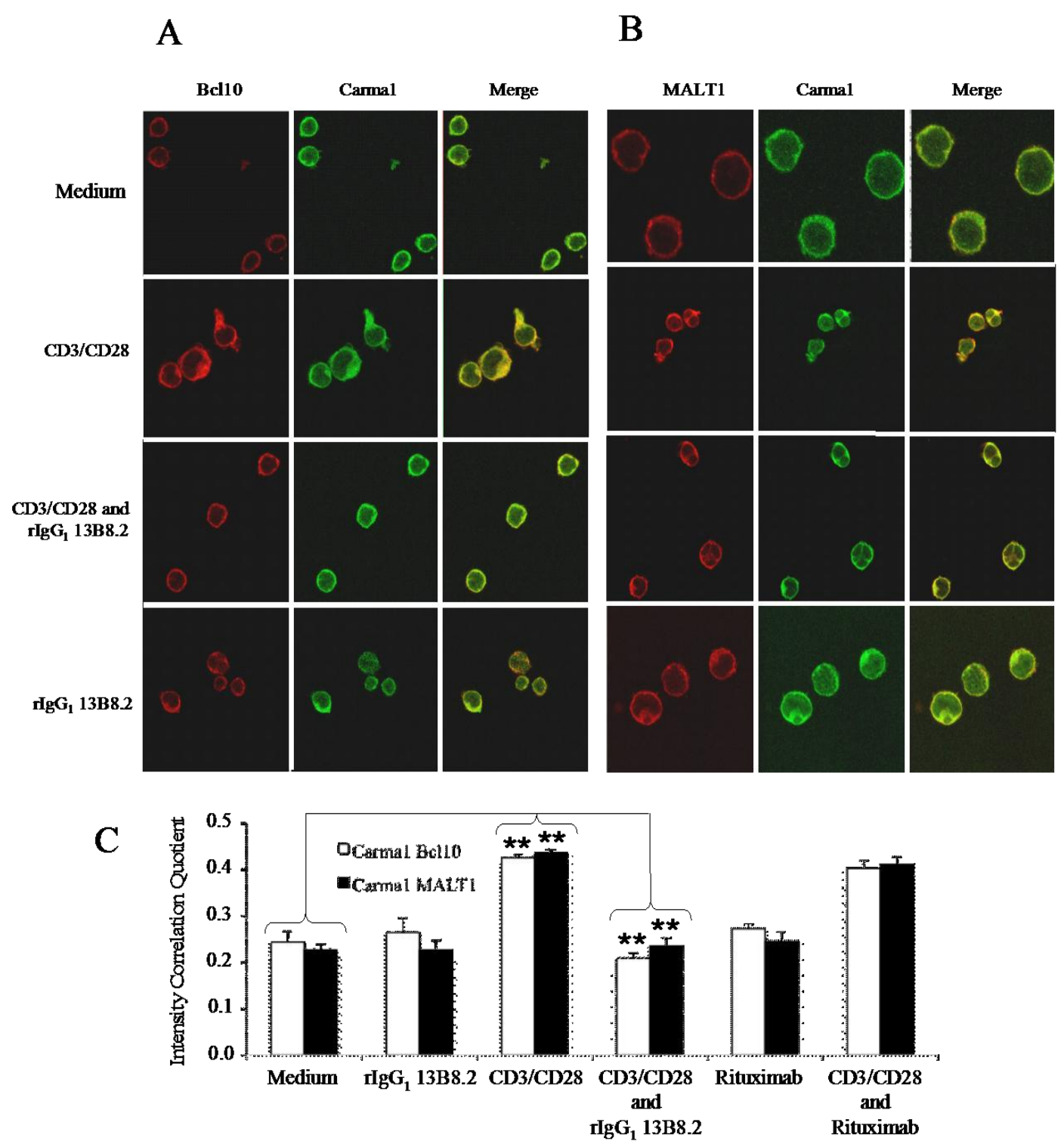